L. Tatar, N. Penkina

\author{
Kharkov State University of Food Technology and Trade
}

\title{
BEER WITH THE PINE NEEDLES EXTRACT ADDITION TOXIC EFFECT RESEARCH
}

Topicality. Alcohol is one of the risk factors for many diseases, including coronary heart disease, stroke, type 2 diabetes mellitus and others. Common world ways in solving this problem in recent years has improved the preparatory technology quality of alcohol and their composition optimization, leading to lessening the negative alcohol effects on the body.

Aim. To investigate the beer toxicological aspects and assess the feasibility of creating a new brewing technology with the addition of an aqueous pine needles extract, which partly replaced by hops.

Materials and methods. Beer prepared on the classical recipe with the addition of pine extract $(600 \mathrm{ml} / \mathrm{dl})$. The influence of beer with the pine needle extract addition on prooxidant-antioxidant status of the animals liver comparing with the beer produced by the classical recipe.

Results and discussion. The animals were given the beer examples produced by classical technology at a dose of $15 \mathrm{~g} / \mathrm{kg}$ for a period of 14 days significantly increased the content of oxidative markers in the liver homogenate (GC $20.4 \%$, TBA-reagents - 51.6\%) compared to animals that received placebo and reduced activity catalase - by $40.9 \%$. Biomarkers in liver homogenate of animals treated beer with an pine needles extract were within the physiological norm. Under the influence of prednisolone $(50 \mathrm{mg} / \mathrm{kg}$ ) dien conjugates content in the liver of animals treated with classical technologies beer by $23.8 \%$ more than in animals that under conditions of oxidative stress used purified water. The content of TBA-reagents over $13.7 \%$, glutathione content less than $25.0 \%$ compared to the placebo group. In animals treated with beer extract of pine needles all anti-oxidative markers of liver catalase activity are significantly differed from that of animals that used purified water. In animals treated with the classic beer technology under normobaric hypoxia model was likely reduce the average lifetime to $313.1 \mathrm{~s}$ in terms of lack of oxygen compared to animals treated with purified water. In animals administrated with beer extract of pine needles average lifetime remained intact at figures and had no probable deviations.

Conclusions. According to biochemical markers research of anti-oxidative system in liver homogenate of animals, beer with pine needles extract, due to its antioxidative properties, minimizes the negative alcohol impact on the liver that manifested in less oxidative stress. Beer with pine needles extract does not potentiate the adverse effects of alcohol in acute hypoxic condition and does not reduce the average lifetime of the animal, as opposed to the usual beer. A beer "Emerald" with an extract of pine needles, due to its antioxidant properties, may be an alternative to modern alcoholic beverages and significantly reduce the toxic effects of alcohol.

Key words: pine needles; beer; antioxidant properties; oxidative stress.

\section{Л. В. Татар, Н. М. Пєнкіна}

\section{Дослідження токсикологічного впливу пива з додаванням екстракту хвої сосни}

Мета роботи - дослідити токсикологічні аспекти пива та оцінити доцільність створення нової технології приготування пива з додаванням водного екстракту хвої сосни звичайної, якою частково замінили хміль.

Матеріали та методи. Пиво приготували за класичною рецептурою з додаванням хвойного екстракту (600 мл/дал). Вивчали вплив пива з додаванням екстракту хвої сосни звичайної на прооксидантно-антиоксидантний стан печінки тварин порівняно з пивом, виготовленим за класичною рецептурою.

Результати та їх обговорення. Уведення тваринам пива, виготовленого за класичною технологією, в дозі 15 г/кг протягом 14 днів вірогідно підвищувало вміст прооксидантних маркерів у гомогенаті печінки (ДК на 20,4 \%, ТБК-реактантів - на 51,6 \%) порівняно з тваринами, що отримували плацебо, та зменшувало активність каталази на 40,9%. Маркери гомогенату печінки тварин, які отримували пиво з екстрактом, знаходилися в межах фізіологічної норми. Під впливом преднізолону (50 мг/кг) вміст дієнових кон`югатів в печінці тварин, що отримували зазначене пиво, збільшувався на 23,8 \% порівняно з тваринами, які в умовах оксидативного стресу вживали воду очищену. Вміст ТБК-реактантів більше на 13,7 \%, вміст відновленого глутатіону менше на 25,0 \% порівняно з групою плацебо. У тварин, що отримували пиво з екстрактом, усі маркери анти-прооксидантної системи печінки й активність каталази вірогідно не відрізнялися від показників тварин, які вживали воду очищену. У тварин, які отримували пиво на моделі нормобаричної гіпоксії, було вірогідне зменшення середнього часу життя на 313,1 с за умови недостатності кисню порівняно з тваринами, що отримували воду очищену. У тварин, яким уводили пиво з екстрактом, середній час життя залишався на рівні інтактних показників та не мав вірогідних відхилень.

Висновки. Розроблене пиво завдяки своїм антиоксидантним властивостям, вірогідно зменшить токсичний вплив алкоголю на організм людини та стане альтернативою сучасним алкогольним напоям.

Ключові слова: хвоя сосни; пиво; антиоксидантні властивості; оксидативний стрес

\author{
Н. М. Пенкина, Л. В. Татар \\ Исследование токсикологического влияния пива с добавлением экстракта хвои сосны \\ Цель работы - исследовать токсикологические аспекты пива и оценить целесообразность создания новой \\ технологии приготовления пива с добавлением водного экстракта хвои сосны обыкновенной, которой частич- \\ но заменили хмель.
}


Материалы и методы. Пиво приготовлено по классической рецептуре с добавлением хвойного экстракта (600 мл/дал). Изучали влияние пива с добавлением экстракта хвои сосны обыкновенной на прооксидантно-антиоксидантное состояние печени животных по сравнению с пивом изготовленным по классической рецептуре.

Результаты и их обсуждение. Введение животным пива классической технологии в дозе 15 г/кг в течение 14 дней достоверно повышало содержание прооксидантных маркеров в гомогенате печени (ДК на 20,4 \%, ТБК-реактантов - на 51,6 \%) по сравнению с животными, получавшими плацебо и уменьшало активность каталазы на 40,9 \%. Маркеры гомогената печени животных, получавших пиво с экстрактом находились в рамках физиологической нормы. Под влиянием преднизолона (50 мг/кг) содержание диеновых коньюгатов в печени животных, получавших пиво классической технологии на 23,8 \% больше, чем у животных, в условиях оксидативного стресса употребляли воду очищенную. Содержание ТБК-реактантов больше на 13,7 \%, содержание восстановленного глутатиона меньше на 25,0 \% по сравнению с группой плацебо. У животных, получавших пиво с экстрактом все маркеры анти-прооксидантного системы печени и активность каталазы достоверно не отличались от показателей животных, употреблявших воду очищенную. У животных, получавших пиво классической технологии на модели нормобарической гипоксии, было достоверное уменьшение среднего времени жизни на 313,1 с в условиях недостаточности кислорода по сравнению с животными, получавшими воду очищенную. У животных, которым вводили пиво с экстрактом среднее время жизни оставался на уровне интактных показателей и не имел достоверных отклонений.

Выводы. Разработанное пиво благодаря своим антиоксидантным свойствам вероятно уменьшит токсическое действие алкоголя на организм человека и может быть альтернативой современным алкогольным напиткам.

Ключевые слова: хвоя сосны; пиво; антиоксидантные свойства; оксидативный стресс

\section{INTRODUCTION}

Taking alcohol is one of the risk factors for many diseases, including coronary heart disease, stroke, type 2 diabetes mellitus and others. Despite government social programs to fight against excessive consumption of alcoholic beverages, in everyday life it is almost impossible to eliminate it completely, most people rarely use alcohol in moderation and not an abuse, but also such alcohol regime is not good for the body [1]. Common world ways in solving this problem in recent years has improved the preparatory technology quality of alcohol and their composition optimization, leading to reduction the negative alcohol effects on the body.

Even in some cases to provide some useful dietary properties (within the components extension for the benefit of food containing healthy nutrients) [2-4].

Plant extract adding to beer and soft drinks is able to improve the quality of their properties and reduce the toxic alcohol effects on the body. Hops gives beer a special taste and odour, but the results of recent studies by some scientists give grounds to assert that hops negative impact on the human organism [5, 6]. Adding extract of pine needles during brewing allows enrich product variety of biologically active compounds, avoid preservatives and reduce the mass fraction of hops in the drink.

The pine extract composition includes antioxidative vitamins $(\mathrm{A}, \mathrm{E}, \mathrm{C})$ preventing the free radical processes flow and increase the beverage chemical stability, other organic compounds (resins, fat organic acids, essential oils, glycosides, phenols), with antioxidative, antimicrobial and restorative properties [7].

The presence of reactive oxygen species (ROS), free radicals and lipid peroxidation products (LPO) characteristic of the pathological processes course. These processes are enhanced hypoxia and it is one of the main factors of brain damage and other organs [8]. In its turn, alcohol influence on the living beings also increases the ROS release and lipid peroxidation processes (especially in the liver and brain), alcohol is especially toxic for tissues.
Adding the antioxidants to the soft drinks can reduce oxidative and toxic alcohol effects $[9,10]$. Besides these strong drinks contain small amount of micro- and macronutrients, vitamins and organic acids, thus beer beverages enriching with such items may be useful for consumers diet. Being added to alcoholic beverages harmless, antimicrobial fungicidal substances of natural origin can improve quality product indicators (term storage, preservation of taste), to prevent contamination by microorganisms and the use of preservatives in beverage technology. These benefits are theoretically justify the appropriateness of adding phytoextracts beer products, namely an pine needles extract that meets all the above requirements.

The aim of the present work was to investigate the beer toxicological aspects and assess the feasibility of creating a new brewing technology using a pine needles water extract, which partially replaced the hops (intragastric administration to the animals within 14 days once a day). The study conducted at the Central Research Laboratory in the National University of Pharmacy, which certified by the State Expert Center MOH in Ukraine as a base research on experimental pharmacology. Before the experiment, the animals were in the room for acclimatization test for seven days; animals were quarantined and appropriate acclimatization in accordance with current regulations.

\section{MATERIAL AND METHODS}

The object of investigation was a $10 \%$ sample of lager "Emerald" (prescription warehouse approved at a meeting of the Specialized Industrial tasting commission to assess the beer quality, soft drinks, alcoholic beverages, mineral and drinking water, syrups and concentrates, Ukrpivo, 15.09.2016) which structure includes pine needles extract. The water extract of plant material obtained by maceration in an amount of $600 \mathrm{ml} / \mathrm{dl}$. Mass fraction of solids extract was $3.25 \%$. Mass fraction of alcohol in beer is $2.9 \%$. To investigate the pine needles extract influence on specific properties of beer evaluated by the antioxi- 


\section{EXPOSURE EXPERIMENTAL GROUPS}

\begin{tabular}{|c|c|c|}
\hline The substance that was injected & Dose, $\mathrm{g} / \mathrm{kg}$ & Term, day \\
\hline \multicolumn{3}{|c|}{ Animals of intact control } \\
\hline Purified water & \multirow{3}{*}{15} & \multirow{3}{*}{14} \\
\hline Beer is produced by classical techno & & \\
\hline Beer with an extract of pine needles & & \\
\hline \multicolumn{3}{|c|}{ Animals with experimentally reproduced oxidative stress } \\
\hline Purified water & \multirow{3}{*}{15} & \multirow{3}{*}{14} \\
\hline Beer is produced by classical techno & & \\
\hline Beer with an extract of pine needles & & \\
\hline
\end{tabular}

dant system indices of animals being given the product, under normal conditions and under high oxidation (oxidative stress, hypoxia). In the pilot study used dose of drink was $15 \mathrm{~g} / \mathrm{kg}$ intragastric administration for animal equivalent to the average number of alcoholic beverage consumed by single person.

Frequent use of alcohol leads to increased free radicals and pro-oxidant processes. Chronically high content of free radicals, in turn, causes the activation of metabolic pathways in the body, disturbances of homeostasis, demonstrates also other dangerous diseases. Particular damage by alcohol takes place, if in the body is formation of free radicals dominated over the antioxidant processes, which under normal conditions would have coped with the impact of alcohol on the release of ROS. Therefore, it is advisable to investigate the influence of beer product from pine needles on oxidation decrement. Subhronicl suppression of antioxidant system of the body was reproduced under the model of oxidative stress [11]. Experiments performed on 36 white nonlinear rats weighing 220-250 g of both sexes, divided into six groups (Tab. 1). For the relevant interpreting the results of the experiment consisted in comparing the impact of water, beer, made on classic technology and beer pine needles under normal terms and conditions of oxidative stress.

Oxidative stress modeled by the standard method (glucocorticoid-induced oxidative stress) by intraperitoneal administration of prednisolone daily in dose $50 \mathrm{mg} / \mathrm{kg}$ for 14 days [12]. Three hours after the injection began to enter studied beverage in dose $15 \mathrm{~g} / \mathrm{kg}$. Intact animals was administered the appropriate amount of purified water. It is expedient to investigate the effect of these drinks on a pro-antioxidant balance in terms of liver degraded condition. On the 14th day of the experiment the animals were taken out and examined their liver homogenates lenels pf antioxidants (SH, catalase) and oxidative (DCreagents TBA) markers by standard methods.

The impact of the research object on the functional state of the organism in acute pathological condition performed on a model of acute normobaric hypoxia. For the experiment, used 18 white nonlinear mice weighing 20-30 g sexes divided into three experimental groups (six animals in each). For 14 days, every day before modeling hypoxia mice at a dose of $15 \mathrm{~g} / \mathrm{kg}$ intragastric injected

\section{THE CONTENT OF THE ANTIOXIDANT-MARKERS IN MICE LIVER HOMOGENATE AFTER 14 DAYS INTRAGASTRIC ADMINISTRATION BEVERAGES STUDIED IN TERMS OF MODELING OXIDATIVE STRESS, $n=6$}

\begin{tabular}{|c|c|c|c|}
\hline $\begin{array}{c}\text { Diene } \\
\text { conjugates } \\
(\mathrm{mmol} / \mathrm{g})\end{array}$ & $\begin{array}{c}\text { TBA-reagents } \\
(\mathrm{mmol} / \mathrm{g})\end{array}$ & $\begin{array}{c}\text { Reduced } \\
\text { glutathione } \\
(\mathrm{mg} / \mathrm{g})\end{array}$ & $\begin{array}{c}\text { The activity } \\
\text { of catalase } \\
(\mathrm{mmol} / \mathrm{min} \cdot \mathrm{d})\end{array}$ \\
\hline \multicolumn{4}{|c|}{ Groups of animals intact control } \\
\hline $9.8 \pm 0.8$ & $6.2 \pm 0.6$ & $13.2 \pm 0.4$ & $6.1 \pm 0.8$ \\
\hline $11.8 \pm 0.5^{*}$ & $9.4 \pm 0.7^{*}$ & $12.4 \pm 1.2$ & $3.6 \pm 1.1^{*}$ \\
\hline $9.2 \pm 0.9$ & $6.9 \pm 0.3$ & $13.6 \pm 1.5$ & $5.6 \pm 0.8$ \\
\hline \multicolumn{4}{|c|}{ Groups of animals with simulated pathology } \\
\hline $21.4 \pm 1.9$ & $16.8 \pm 0.9$ & $5.6 \pm 0.5$ & $2.1 \pm 0.4$ \\
\hline $26.5 \pm 1.5^{*}$ & $19.1 \pm 1.2^{*}$ & $4.2 \pm 0.8^{*}$ & $1.8 \pm 0.6$ \\
\hline $22.3 \pm 0.7$ & $16.5 \pm 1.4$ & $5.3 \pm 0.4$ & $2.0 \pm 0.5$ \\
\hline
\end{tabular}

Notes: * Changing values likely in groups of animals that received placebo (water): intact animal control - the indicator of number 1 , the control of animal pathology - index of number $4(p<0.05)$.

water, the usual beer and beer with an extract of pine needles. Research on the model of acute normobaric hypoxia performed by keeping the animals in a closed special container volume of $200 \mathrm{~cm}^{3}$ and a maximum - recorded life and thanatogenesis symptoms [13].

The experimental data treated statistically by variation statistics. Experimental data processed by methods of variation statistics using a standard software package "Statistica 6.0" via U-Mann-Whitney [14].

\section{RESULTS AND DISCUSSION}

Biochemical parameters measured in liver homogenate of animals without lesions showed that the use of animals beer produced by classical technology at a dose $15 \mathrm{~g} / \mathrm{kg}$ within 14 days significantly increased the content of oxidative markers in liver homogenate: GC content increased on $20.4 \%$, and the content of TBA-reagents on $51.6 \%$ compared to animals that received placebo during the experiment (purified water). Regarding the antioxidant status of the liver tissues of animals: $\mathrm{SH}$ content remained at levels in intact, but significantly decreased catalase activity - by $40.9 \%$. The findings suggest that even relatively healthy person prolonged alcohol abuse can cause disruption of liver antioxidant system and body as a whole (Tab. 2).

However, in liver homogenates of animals treated with beer contains an extract of pine needles not all the parameters differed from homogenate animals, which was administered water instead of alcoholic beverage. All mar kers of antioxidant-system were within the physiological norm. This suggests that antioxidants contained in the extract of pine needles, offset the negative impact of alcohol and other harmful components of beer (Tab. 2). According to a survey conducted on the model of oxidative stress, shows that exposure to prednisone $50 \mathrm{mg} / \mathrm{kg}$, which was administered to mice intraperitoneally for 
14 days, the animals formed persistent breach notable anti-oxidative system in liver tissue. All indices of antioxidative system of the liver in these animals is significantly different from equivalent performance intact animals respective groups (Tab. 2). Defeat antioxidant system in the liver of animals treated drinking, made on classic technology were strongest among all groups. The diene conjugates content in the liver of these animals was $23.8 \%$ higher than those in oxidative stress conditions used purified water. The content of TBA-reagents was also significantly more than in the animals from group 4 - by $13.7 \%$. The content of reduced glutathione in the liver of these animals decreased by $25.0 \%$ compared to the placebo (control) that attest tte high oxidation (Tab. 2).

In animals treated with beer extract of pine needles under oxidative stress detected that such processes was appropriative in comparison with the intact group. All studied anti-oxidative markers of liver, DC, TBA-reagents, VG and catalase activity - probably no different from that of animals of group 4, that used purified water (Tab. 2).

Results of the investigation of the antioxidant properties of beer with an extract of pine needles under conditions of oxidative stress show that the drink has an antioxidant capacity that is able to protect the liver from the adverse effects of alcohol both in normal conditions and in conditions of enhanced oxidation, while classic beers only potentiates pro-oxidative processes caused prednisolone, further damaging hepatocytes.

According to the results of this phase of the study, we can conclude that beer with an extract of pine needles in no case is proof-impaired antioxidant status. However, adding an extract of pine needles can minimize the negative impact of the same drink, to which it is included, which provides a favorable profile of noxious product and is an important advantage when implementing a drink to mass production.

Results of the researc of influence of beer with an extract of pine needles in acute pathological conditions obtained on a model normobaric hypoxia. The data indicate that animals that received within 14 days of beer produced by classical technology, noted the likely reduce the average lifetime at $313.1 \mathrm{~s}$ in oxygen deficiency compared with animals treated with purified water. This can explained by the fact that against alcohol strengthens the negative impact of hypoxia on brain processes and po-
Table 3

\section{RESULTS OF THE RESEARCH OF INFLUENCE OF ALCOHOLIC BEVERAGES UNDER THE MODEL OF NORMOBARIC HYPOXIA}

\begin{tabular}{|l|c|}
\hline \multicolumn{1}{|c|}{ The experimental group $(\mathrm{n}=6)$} & $\begin{array}{c}\text { The average lifetime } \\
\text { of animals }(\mathrm{M} \pm \mathrm{m}), \mathrm{s}\end{array}$ \\
\hline Intact control (purified water) & $1523.5 \pm 67.1$ \\
\hline $\begin{array}{l}\text { Beer is produced by classical } \\
\text { technology }\end{array}$ & $1210.4 \pm 45.9^{*}$ \\
\hline Beer with an extract of pine needles & $1498.6 \pm 52.4$ \\
\hline
\end{tabular}

Notes: ${ }^{*}$ Change probable, on the values of intact animal controls $(\mathrm{p}<0,05)$.

tentiates LPO in brain tissues. On the other hand, the animals, which was administered by beer with an extract of pine needles, the average lifetime under experimental normobaric hypoxia remained in intact level and had no plausible differences (Tab. 3).

Assessing the impact of adding an extract of pine needles on the properties of beer in acute pathological condition shows that consumption of this product instead of beer produced by classical technology capable of reducing oxidative effect of the alcohol on the brain. However, the use of conventional alcoholic drinks that contain antioxidants is a serious threat to life in conditions of acute pathological conditions associated with hypoxia.

\section{CONCLUSIONS}

1. According to biochemical markers research of antioxidative system in liver homogenate of animals, beer with pine needles extract, due to its antioxidative properties, minimizes the negative alcohol impact on the liver in high oxidation (oxidative stress).

2. Beer with pine needles extract does not potentiate the adverse effects of alcohol in acute hypoxic condition of the body and does not reduce the average lifetime of the animal, as opposed to the usual beer.

3. A beer "Emerald" with an extract of pine needles, due to its antioxidant properties, may be an alternative to modern alcoholic beverages and significantly reduce the toxic effects of alcohol on the human organism.

Conflicts of Interest: authors have no conflict of interest to declare.

\section{REFERENCES}

1. Deitrich, R. Oxidation of Ethanol in the Brain and Its Consequences / R. Deitrich, S. Zimatkin, S. Pronko // Alcohol Res. and Health. - 2006. - Vol. 29, Issue 4. - P. 266-273.

2. Кучинська, А. М. Наукові засади вибору рослинної сировини для підвищення харчової цінності пива / А. М. Кучинська // Вісник Чернігівського державного університету. - 2013. - № 3 (67). - С. 264-273.

3. Косминский, Г. И. Разработка технологии новых сортов пива на основе пряно-ароматического сырья / Г. И. Косминский, Е. А. Козлова, Н. Г. Царева // Пищевая промышленность: наука и технологии. - 2011. - № 4 (14). - С. 11-15.

4. Patent WO2004/078904 A1. Method for Flavouring Beer and a Flavoured Beer / Y. Arvid. - C12C5/00, 125/02, № PCT/NO2003/000080; declared 17.03.2003; published 16.09.2004.

5. The endocrine activities of 8-prenylnaringenin and related hop (Humulus lupulus L.) flavonoids / S. R. Milligan et al. // J. of Clinical Endocrinology and Metabolism. - 2000. - Vol. 85. - P. 4912-4915. doi: 10.1210/jc.85.12.4912.

6. Effects of moderate alcohol consumption on cognitive function in women / M. J. Stampfer et al. // The New England Journal of Medicine. - 2005. Vol. 352, Issue 3. - P. 245-253. doi:10.1056/nejmoa041152 
7. Chemical composition, antioxidant and antimicrobial activities of essential oil from pine needle (Cedrus deodara) // W. C. Zeng, Y. Zhang, H. Gao et al. // J. Food Sci. - 2012. - Vol. 77, Issue 7. - P. C824-C829. doi: 10.1111/j.1750-3841.2012.02767.x

8. Lewen, A. Oxidative stress-dependent release of mitochondrial cytochrome c after traumatic brain injury / A. Lewen, M. Fujimura, T. Sugawara // J. of Cerebral Blood Flow \& Metabolism. - 2001. - Vol. 21, Issue 8. - P. 914-920. doi: 10.1097/00004647-200108000-00003

9. Research of the toxicological and pharmacological effects of new blends on the body of biological objects / N. Penkina, L. Tatar, G. Zaychenko, D. Lytkin // Ukrainian Food J. - 2015. - Vol. 4, Issue 4. - P. 577-586.

10. Bensafi, M. Ways to reduce the toxic effects of alcohol due to the introduction of antioxidants / M. Bensafi, C. Rouby // Neurosci. Lett. - 2002. - Vol. 328, Issue 3. - P. 309-313.

11. Меньщикова, Е. Б. Окислительный стресс. Патологические заболевания и состояния / Е. Б. Меньщикова, Н. К. Зенков, В. З. Ланкин. Новосибирск, 2008. - 283 с.

12. Зиганшина, Л. Е. Сравнительное изучение эффективности димефосфона и ксидофона при стероидном остеопорозе у крыс / Л. Е. Зиганшина, 3. А. Бурнашева, И. Х. Валеева // Экспериментальная и клиническая фармакол. - 2002. - № 6. - С. 55-56.

13. Руководство по экспериментальному (доклиническому) изучению новых фармакологических веществ / под общ. ред. Р. У. Хабриева. Изд. 2-е, перераб. и доп. - М. : Медицина, 2005. - 832 с.

14. Халафян, А. А. STATISTICA 6. Статистический анализ данных / А. А. Халафян. - М. : Бином-Пресс, - Изд. 3-е., 2007. - 512 с.

\section{REFERENCES}

1. Deitrich, R., Zimatkin, S., Pronko, S. (2006). Oxidation of Ethanol in the Brain and Its Consequences, Alcohol Research and Health, 29 (4), 266-273.

2. Kuchynska, A. M. (2013). Visnyk Chernihivskoho derzhavnoho universytetu, 3 (67), 264-273.

3. Kosminskii, G. I., Kozlova, E. A., Careva, N. G. (2011). Pishchevaia promyshlennost: nauka i tekhnologii, 4 (14), 11-15.

4. Arvid, Ystad. (2004). Patent W02004/078904 A1. Method for Flavouring Beer and a Flavoured Beer. C12C5/00, 125/02, № PCT/NO2003/000080. declared 17.03.2003; published 16.09.2004.

5. Milligan, S. R. (2000). The Endocrine Activities of 8-Prenylnaringenin and Related Hop (Humulus lupulus L.) Flavonoids. Journal of Clinical Endocrinology \& Metabolism, 85 (12), 4912-4915. doi: 10.1210/jc.85.12.4912

6. Stampfer, M. J., Kang, J. H., Chen, J., Cherry, R., Grodstein, F. (2005). Effects of Moderate Alcohol Consumption on Cognitive Function in Women. New England Journal of Medicine, 352 (3), 245-253. doi: 10.1056/nejmoa041152

7. Zeng, W.-C., Zhang, Z., Gao, H., Jia, L.-R., He, Q. (2012). Chemical Composition, Antioxidant, and Antimicrobial Activities of Essential Oil from Pine Needle (Cedrus deodara). Journal of Food Science, 77 (7), C824-C829. doi: 10.1111/j.1750-3841.2012.02767.x

8. Lewen, A., Fujimura, M., Sugawara, T., Matz, P., Copin, J.-C., Chan, P. H. (2001). Oxidative Stress-Dependent Release of Mitochondrial Cytochrome c After Traumatic Brain Injury. Journal of Cerebral Blood Flow \& Metabolism, 914-920. doi: 10.1097/00004647-200108000-00003

9. Penkina, N., Tatar, L., Zaichenko, G., Lytkin, D. (2015). Research of the toxicological and pharmacological effects of new blends on the body of biological objects. Ukranian Food Journal, 4 (4), 577-586.

10. Bensafi, M., Rouby, C. (2002). Ways to reduce the toxic effects of alcohol due to the introduction of antioxidants. Neuroscience Letters, 328 (3), $309-313$.

11. Menshchikova, E. B., Zenkov, N. K., Lankin ,V. Z. (2008). Okislitelnyi stress. Patologicheskie zabolevaniia i sostoianiia. Novosibirsk: ARTA, 283.

12. Ziganshina, L. E., Burnasheva, Z. A., Valeeva, I. H. (2002). Eksperimentalnaia i klinicheskaia farmakologiia, 6, 55-56.

13. Habrieva, R. U. (Eds.). (2005). Rukovodstvo po ehksperimentalnomu (doklinicheskomu) izucheniiu novyh farmakologicheskih veshchestv. (2nd ed.). Moskva: Medicina, 832.

14. Halafian, A. A. (2007). STATISTICA 6. Statisticheskii analiz dannyh. (3d ed.). Moskva: Binom-Press, 512.

\section{Information about authors:}

Tatar L., graduate student of merchandise in customs, Kharkiv State University of Food Technology and Trade. E-mail: tornado.1972@mail.ru. ORCID - http://orcid.org/0000-0002-3432-2142

Penkina N., Ph. D., assistant professor of merchandise in customs, Kharkiv State University of Food Technology and Trade.

E-mail: penkina-nataliya@rambler.ru. ORCID - http://orcid.org/0000-00032-0125-4275

Відомості про авторів:

Татар Л. В., аспірант кафедри товарознавства в митній справі, Харківський державний університет харчування та торгівлі.

E-mail: tornado.1972@mail.ru. ORCID - http://orcid.org/0000-0002-3432-2142

Пенкіна Н. М., канд. техн. н., E-mail: penkina-nataliya@rambler.ru. ORCID - http://orcid.org/0000-00032-0125-4275

доцент кафедри товарознавства в митній справі, Харківський державний університет харчування та торгівлі.

E-mail: penkina-nataliya@rambler.ru. ORCID - http://orcid.org/0000-00032-0125-4275

Сведения об авторах:

Татар Л. В., аспирант кафедры товароведения в таможенном деле, Харьковский государственный университет питания и торговли.

E-mail: tornado.1972@mail.ru. ORCID - http://orcid.org/0000-0002-3432-2142

Пенкина Н. М., канд. техн. н., доцент кафедры товароведения в таможенном деле, Харьковский государственный университет питания и торговки. E-mail: penkina-nataliya@rambler.ru. ORCID - http://orcid.org/0000-00032-0125-4275

Рекомендовано д. біол. н., професором А. Л. Загайком

Надійшла до редакції 20.01.2017 р. 